\title{
A Critical Appraisal of the Method of Revocation in the Nigerian Land Use Act and Government's Compliance
}

\author{
Emuobo Emudainohwo \\ Faculty of Law, Delta State University, Oleh Campus, Oleh, Nigeria \\ Email: eemuobo@yahoo.co.uk
}

How to cite this paper: Emudainohwo, E. (2021). A Critical Appraisal of the Method of Revocation in the Nigerian Land Use Act and Government's Compliance. Beijing Law Review, 12, 750-761.

https://doi.org/10.4236/blr.2021.123039

Received: January 10, 2021

Accepted: July 23, 2021

Published: July 26, 2021

Copyright $\odot 2021$ by author(s) and Scientific Research Publishing Inc. This work is licensed under the Creative Commons Attribution International License (CC BY 4.0).

http://creativecommons.org/licenses/by/4.0/

\section{(c) (i) Open Access}

\begin{abstract}
The paper inquires whether there is government's compliance with the method of revocation of right of occupancy stipulated in the Land Use Act (LUA) (1978). The LUA has prescribed the procedure for the revocation of right of occupancy. It is expected that government complies with the procedure. There have been cases where government did follow laid down procedure for the revocation of right occupancy. Therefore, when government flouts laws regulating the procedure for the acquisition of private property, it is the obligation of the Nigerian courts to intervene in favour of the private citizen. Though the courts are obliged to intervene, the question is: what happens, when government disobeys court orders? Or what happens when private citizens for lack of means did not challenge in court any wrong procedure adopted by government? Apart from calling for more judicial activism in this area, the paper argued that government should follow laid down procedure for the acquisition of private property; for even God who has laid down the procedure for man to be holy has also subjected himself to holiness.
\end{abstract}

\section{Keywords}

Land Use Act, Revocation, Right of Occupancy, Compliance, Nigeria

\section{Introduction}

The aim of the research is to investigate government's compliance with the method of revocation of right of occupancy stipulated in the LUA (1978). The right of an individual to own property guaranteed in section 43 of the Constitution. One incident of ownership is the right of the landowner to enjoy and use his property to the exclusion of others, such right is curtailed through the strict ap- 
plication of the eminent domain Kratovil and Harrison (1954).

Today a landowner's right in respect of his property is subject to governmental power to compulsorily acquire such land by revoking the existing interest on the land for overall public interest (LUA section 28) subject, however, to the payment compensation to the owner of the acquired land (Constitution section 44(1) and LUA section 29(1). It is in view of this that the LUA laid down the procedure through which government could compulsorily acquire land (LUA sections 28(6)(7) and 29(1)(2). This Paper will examine the extent of government's compliance with this procedure. The LUA was promulgated in 1978. It provided for a method of land acquisition not known in native land tenure (Otubu, 2012). It vests all lands in the territory of each state in the Governor who is to hold same in trust for all Nigerians. It then created a proprietary interest in land known as right of occupancy which is lesser than ownership. The right of occupancy is limited in duration and also defeasible under some conditions. From the promulgation of the LUA, the reversion in all lands is vested in the state (Otubu, 2012). Therefore, what is stipulated under the LUA is the revocation of the right of occupancy.

\section{Theoretical Perspectives of Compulsory Acquisition}

The word "revocation" was not defined by the LUA, but it has the effect of extinguishing all rights of a possessor of right of occupancy. Usually, the basis for most revocations of rights of occupancy is acquisition of the land for public purpose. The terms "revocation of right of occupancy for public purpose" and "compulsory land acquisition for public purpose" appear to be synonymous, because if either of them (is carried out by the government), it has the effect of extinguishing all existing rights in the land. It is in this light that the theoretical underpinning of compulsory acquisition will be used to explain the term "revocation of right of occupancy" being the term used by the LUA. Compulsory acquisition of land as it relates to the LUA will be explained herein. According to Umeh (1973) compulsory land acquisition is the forcible taking or acquisition of private lands (communal or individual) for public benefits or purposes. Also, Zhang and $\mathrm{Lu}$ (2011) explained compulsory land acquisition as government act of transferring ownership in land from private to state owned where the interest of the public is involved. Furthermore, Otubu (2013) explained it to be government's authority to acquire rights in land without the owner's consent for the benefit of the community. Michelman (1967) explained the justification for compulsory land acquisition to be development of various projects that will benefit the public. Otubu (2013) further explained that without the government's authority to compulsorily acquire private property for public purpose, performance of many desirable projects that will benefit the public will be undermined or frustrated by various holdouts. The LUA recognizes compulsory acquisition as revocation of right of rights of occupancy. And in this regard, section 28 of the LUA empowered the government to revoke rights of occupancy for either 
overriding public interests or for other grounds specified by the LUA. Under section 29 of the LUA, the government is obliged to pay for compensation, where the land is required for public purpose, mining, oil pipelines or purposes connected thereof

\section{Pre 1978 Land Tenure Laws in Nigeria}

Prior to the promulgation of the LUA in 1978, there was no uniform land policy in Nigeria. In the southern parts of the country there was mainly the customary law relating to land in operation whilst in the north statutes mainly regulated the land tenure system. Regarding customary land tenure, various communities had their own rules and customs relating to land which is acceptable and prevailing among the natives where the piece of land is loc: there was therefore no uniform customary land law. Concerning statutory land tenure, the various statutes that regulated land tenure before the LUA are both in the received English law and Nigerian legislations. Under the Received English Law, the Interpretation Act (1958) introduced the common law of England, the doctrines of equity and Statutes of General Application which were in force on the $1^{\text {st }}$ day of January 1900 into Nigeria. By that provision, the English common law of property was made applicable to Nigeria where customary land law was not applicable. Some English statutes which form part of Nigerian principles of Land law are: Statutes of Fraud, Small Tenement Act, Statutes of Distribution, Real Property Limitation, Land Transfer Act, Conveyancing, Recovery of Premises Act, Wills Act and Vendor and Purchasers Act etc. Also, the Nigerian law of mortgages, leases, conveyance and succession which form part of the land law are based on English Law. Under Nigerian legislations, land legislation in Nigeria started as early as 1861 when the colony of Lagos was established. As soon as the colonial administration was established on that date, land legislation like Arotas Grants Act' (1958), Epetedo Grant Acts (1958) and Glover Settlement Act (1958). These statutes regulated land in the colony of Lagos. The lands were largely residential lands. Farm lands were regulated by customary law. In 1900, a general land policy, which covered the whole of what was known as southern protectorate was promulgated. Another regulation, Crown Land Proclamation [1906], was made concerning Crown lands. The Native Lands Acquisition Ordinance [1908] was aimed at prohibiting any alienation of land to an alien by whatever means without the Governor's consent. In 1902, the Land Proclamation [1902] was made in Northern Nigeria. This statute divided the land of the Northern Protectorate into two: crown lands and public lands. The Land and Native Rights Proclamation was promulgated in 1910. The Land and Native Rights Proclamation of 1910 was designated as Land and Native Rights Ordinance in 1916. Under that Ordinance, lands in Northern Nigeria were declared native lands and were the controlled and managed by the colonial governor. The Native Rights Ordinance of 1916 was repealed and replaced by the Lands Tenure Law of Northern Nigeria 1962. Except for minor changes, these policies remained the principles of statu- 
tory land law in the northern Nigeria before the promulgation of the LUA in 1978 Yakubu (1989).

\section{Land Tenure since 1978}

The promulgation of the LUA on the $29^{\text {th }}$ of March 1978 had the effect of bringing the whole of Nigeria under one statutory land law, Yakubu (1989). Prior to the LUA, there was the problem of uncertainty of title particularly under the customary land tenure system in the south Ogunbanlbi v Abowaba [1951] beside this problem of uncertainty of title, the government was finding it extremely difficult to get: land for development. The compensation demanded by individuals for government acquisition of their Lands most times were more than the cost of the public project. It became very imperative that government should intervene through legislation to correct the ills Ojo (2003). The preamble of the LUA sums up its objective, as the rights of Nigerians to the land be preserved by law. The LUA, in the stead of radical title (or ownership, communal or otherwise) introduced right of occupancy as the highest proprietary interest that can be conferred. The inclusion of right of occupancy in the LUA had the effect of extinguishing all forms of ownership (both in customary law and common law) in place of right of occupancy. Section 1 of the LUA vests all lands comprised in each state of the country in the governor of that state and the land would be held and administered for all Nigerians. When Section 1 is construed relating to right of occupancy, the effect is that: since the enactment of the LUA, it is no longer possible to own land allodially. In Salami v Oke [1987], the Supreme. court held that absolute ownership is no longer possible since section 1, of the LUA vest the land in each state of Nigeria in the governor of that state and the land is held for Nigerians. Thus, what is capable of ownership now is the right of occupancy Oluyemi (2005).

\section{Types of Rights of Occupancy}

In the LUA, two different rights of occupancy are stipulated. They are: statutory right of occupancy and customary right of occupancy. Both are of two classifications. The first is statutory right of occupancy given by the state governor in 5(1)(a) of the LUA and the customary right of occupancy given by the local government in section 6(1)(a) of the LUA. The second classification is the statutory right of occupancy given by the state governor (section 34(2) LUA) and the customary right of occupancy given by the local government (section 36(2) LUA). In both cases, there exist an actual grant as and deemed grant. An actual grant is given by the governor of a state or by a local government, while a deemed grant comes by the operation of law Savannah Bank (Nig) Ltd. v Ajilo [1989].

\subsection{Statutory Right of Occupancy}

In section 5 of the LUA, the governor can give statutory right of occupancy to a person whether the land is located in the urban area or not Adeniran v Alao 
[1992]. A person in whom a land is vested by section 34(2) of the LUA is considered to be a holder of statutory right of occupancy delivered by the governor under the LUA Teniola v Olohunkin [1999]. Section 5(2) of the LUA stipulates that once a statutory right of occupancy in section $5(1)$ is given all existing rights to the land is terminated or extinguished. The Supreme court has however held that the rights that will be extinguished are mere licence or usufruct but not rights which are capable in law of being alienated Ibrahim v Mohammed [2003]. Also, where there is a subsisting statutory right of occupancy, the giving of another statutory right of occupancy over the land is invalid. In Ilona v Idakwo [2003], the right of occupancy conferred on the appellants on $24^{\text {th }}$ April 1984 over the disputed land was held invalid by the Supreme court because there was already a subsisting statutory right of occupancy over the land which had not been revoked. A governor has inherent powers to revoke or cancel a right of occupancy if granted in error Ilona v Idakwo [2003]. Also, a governor can cancel such a revocation on discovering that the revocation was made in error.

\subsection{Customary Right of Occupancy}

In Dielu v Iwuno [1996] the Supreme Court stated that by section 6(1) of the LUA, a local government is empowered to give a customary right of occupancy of land not in an urban area for agricultural and other purposes. In Awaogbo $v$ Eze [1995] the Supreme Court also held that section 6, of the LUA deals with the power and ability of a local government concerning land not in urban area. Section 6(3) makes it legal for a local government to access or enter and use land within its area of jurisdiction for public purpose.

\section{Procedure for Revocation}

The LUA expressly laid down the procedure for a valid revocation and they include:

1) the revocation is to be signed by an officer authorized for the purpose by the governor (section 28(6) LUA).

2) notice shall be issued stating the purpose of revocation that is either for public purpose or for breach of conditions of grant Obikoya \& Sons Ltd. v Governor of Lagos State [1997]. A revocation for any purpose outside those pre-scribed can be declared void Ereku v Military Governor of Mid-Western State [1974].

2) notice is required to be served on the holder (section 28(6) LUA). As regards mode of serving the notice, section 44 of the LUA stipulates that:

a) by giving it to the person to be served or;

b) by leaving it at the usual or last residence of that person;

c) by sending a letter to the person's residence;

d) if it is a company by delivering it to clerk or secretary;

e) If not feasible after inquiry about the address of a possessor or holder to be served if no identifiable person in the premises the notice can be affixed in some visible place of the property. 
4) notice must be proved to have come to the knowledge of the person concerned i.e. there must be proof of receipt of such Notice (Attorney General Lagos State v Sowande, 1992).

5) the holder's title only becomes extinguished on the receipt of the Notice or on other date in the Notice (section 28(6) and (7) LUA).

6) where the revocation is for public purpose (as against penal revocation under section 28(5) of the LUA, the holder or possessor or the occupier would be compensated for the value at the land for unexhausted improvements or under any relevant legislation (section 29(1) and (2) LUA).

\section{Non-Compliance on the Part of Government}

In spite of this laid down procedure; there are still cases of non-compliance on the part of government. Non-compliance can either be in the form of improper notice/lack of notice or failure of public purpose.

\subsection{Improper Notice or Lack of Notice}

In Osho v Foreign Finance [1991], the Supreme Court held that the notice of revocation not having been duly served on the plaintiff was invalid. In Nitel v Ogunbiyi [1992], the Court of Appeal nullified a revocation notice that was not personally served on the property owner at the address known to the Government. The facts of the case were fairly straightforward. By a notice issued by the Kwara State Government, it purportedly acquired the respondent's large tract of land adjacent to the General Post Office for the objective of construction of telephone exchange building for the Appellant. The respondent had four structures on the said land and at all material times resident in Lagos, a fact which the appellant conceded. The notice of acquisition was not served on the respondent in Lagos where he resided but was pasted on the building. The respondent thereupon instituted an action challenging the validity of the said acquisition and averred that since the service of the notice was not personal, the revocation was invalid and acquisition illegal. The Nigerian Court of Appeal upheld the respondent's claim that the right was not properly revoked as laid down in section 28(6) LUA. Achike J. C. A. decided that the condition of section 28(6) is that a notice of revocation or cancellation of the right of occupancy should be served personally on the holder and any such notice purporting to revoke right of occupancy by any officer duly authorized by the governor is ineffectual if it fails to comply with this requirement. Explaining the rationale for this, Achike J. C. A. explained that the reason for revocation notice is to notify the possessor of the right of occupancy the process to extinguish his said right of occupancy. And that it is undesirable to accept any substituted service when whereabouts and the residence of the holder is known to the person serving the notice. In Gwar v Adole [2003], notice of cancellation or revocation was not served on the appellant and Mangaji J. C. A. delivering the judgment of the court held that no notice was ever prepared by a officer of governor and also no of service the notice on 
the appellant and as such the certificate of occupancy of the appellant's land is invalid and that title was not revoked by the governor, and his current rights in the land therefore remain extant Gwar v Adole [2003]. Commenting further on the need for proper service, Nnaemeka-Agu J. S. C. in Attorney General of Bendel State v Aideyan [1989] stated that acquiring an individual's property compulsorily is a breach of his right to property and that it only by a proper notice stipulated in law that the owner's rights in the matter can be satisfied and guaranteed.

\subsection{Failure of Purpose and Principle of Reversion}

One area of non-compliance as earlier stated is where there is a failure of purpose. Failure of purpose could arise in many ways. It could arise where portion of the land acquired was used for the public purpose and the remnant shared by the acquiring authority to private individuals Amokaye (2003). The second is where private citizens are divested of their land under section 28 but the Governor later reallocated the land to private interest Amokaye (2003). The question flowing from these scenarios is whether land should be returned to the original owner or the Governor should be allowed to hold onto the land-in trust until when the acquired land will be required for similar public purpose Amokaye (2003). The LUA did not lay down the procedure to follow when there is a failure of purpose but' the issue of failure of purpose has received judicial construction. In Foreign Finance Corporation v Lagos State Development Property Corporation [1991], it was decided that when Government acquired land for public purpose it must be used for that purpose only and when the public purpose a person's land is acquired fails the land reverts back to the original owner, Obikoya \& Sons Ltd. v Governor of Lagos State [1997]. Also, if land is compulsorily obtained for a general purpose A, for instance, it cannot be used for another public purpose. Usage for another public purpose has been interpreted to mean failure of purpose for which the land ought to be returned to the original owner. In Akinde \& ors v Government of Nigeria \& Ors. (2007), the disputed land was acquired for Federal Low Housing Scheme. The original Scheme was abandoned and another-a "Sight and Service" Scheme was introduced. It was held that since the land could no longer be utilized for the reason it was acquired i.e., for Federal Government Low-Cost Housing Scheme, the defendant ought to have returned same to the plaintiffs. Also, where land is acquired for any public purpose and subsequently granted to a private company to execute a programme at a profit for the government it would still be considered as invalid. In Ajibulu v Lawson \& Ors. [1991], the respondent's land was acquired by the Ogun State Government and later granted it to the $2^{\text {nd }}$ appellant, a private company; the court held that the compulsory acquisition of the respondent's land only for the purpose of transferring it to the $2^{\text {nd }}$ appellant (a Private Company) is invalid and not for a public purpose, notwithstanding that the $2^{\text {nd }}$ appellant used the land in carrying out Economic, Industrial and Agricultural Development same govern- 
ment activities.

\section{Compensation}

One issue which arises for consideration after a valid revocation of right of occupancy is compensation for the possessor or holder of the right. Compensation is payable under the LUA if the revocation is for public purpose or for mining of building materials (section 29(1) LUA) and not for a bare land. Also, section 44(1) of the Constitution makes payment of compensation mandatory to the possessor of the right of occupancy which has been revoked. It is pertinent to note that both sections 44(1) of the Constitution and 29(1) of the LUA that make payment of compensation mandatory. The Supreme Court also confirmed the right of a citizen to compensation. In Osho v Foreign Finance \& Anor [1991] it noted that a citizen whose right of occupancy has been revoked is entitled to compensation under section 29(1) of that LUA. Compensation is not a pre-requisite to valid revocation but only a fall out of it. Where a right of occupancy revoked is in respect of land required for mining purpose or oil pipelines or other purposes connected with the mining and oil pipeline, the occupier will be qualified for compensation in the appropriate legislation of the Mineral Act or Mineral Oil Act or any law after it (section 29(1) and (2) LUA).

\subsection{Non-Entitlement to Compensation}

One worrisome aspect of the LUA is that when the occupancy right is cancelled or revoked for public purpose only the "holder" and "occupier" that are entitled to compensation for the value of their unexhausted improvements on the land (section 29(1) and (2) LUA. The meaning of "holder" and "occupier" under the LUA does not include the mortgagee (section 51 LUA). This may have the effect that though the mortgagee has right to improvements in the land, (which is a security for, his debt) yet on revocation, the mortgagee has no right to the compensation money Essien (2003). It appears that there is no judicial pronouncement on the point in Nigeria. However, the issue arose in the Tanzanian case of Manyara Estates Ltd. \& Ors v. National Development Credit Agency [1970] where in the Land Ordinance (1923) compensation for improvements on land in a revocation of the right of occupancy was only payable to the "occupier". It was stated that a mortgagee was not an "occupier" and by this he was not qualified for compensation, and that the agreement designed by the mortgage did not attach compensation. The court also started further that the doctrine of tracing is not applicable in the circumstances because of the absence of any fiduciary relationship in the part of the paying authority to the mortgagee. The non-entitlement of compensation to a mortgagee under the LUA shows the precariousness of the right of occupancy as a mortgage security. James (1987) has made the following suggestion as a way out of such problem when he said that: a provision could be inserted in a law which state that compensation payable to the right holder should be applied to satisfy any mortgage debts in order of precedence. And that 
if no law in this regard a clause should be in the mortgage document stating that a mortgage debt should be additionally secured by compensation paid to the mortgagor for any unexhausted improvements.

\subsection{Adequacy of Compensation and Resettlement}

Another important issue that should be examined is whether compensation or resettlement as stipulated in the LUA is adequate or not. The compensation due is the sum equivalent to rent paid by the occupier when the right of occupancy is revoked (section 29(4)(a) LUA). This means that if a person paid no rent, he is not qualified for compensation but his piece of land is taken away compulsorily' by the government Ikpe (1978). The implication of this provision is that compensation cannot also be paid for bare land. This is inadequate. If the Constitution (section 44(1) provides for compensation both movable and immovable property, and bare land is an immovable property, then compensation should be paid for its acquisition. Regarding buildings, installations and improvements in the land, the compensation to be paid is the cost of replacement as determined or assessed by the designated officer minus the depreciation plus interest at the current bank rate for any delay in compensation (section 29(4)(b) LUA). This will only be adequate if the officer that determined the cost of replacement adopts the current market value of such property. Regarding, crops on in the land, the compensation to be paid is a sum equal to the value determined by the designated officer (section 29(4)(c) LUA). This also is not adequate, it is suggested that an alternative land should be provided in addition to payment of the crops. This may be important in encouraging agriculture. Generally, it is, suggested that, compensation should be paid for loss of use of a right of occupancy and for "disturbance" for all the instances of section 29(4) of the LUA. On the issue of resettlement of displaced persons, where land in respect of which a customary occupancy right is revoked and the land was utilized for farming purposes by the possessor, he is eligible for another land for the purpose (section 6(6) LUA). This is fair enough or else many farmers will be displaced and sent out of job where they are not provided with any other alternative and this can lead to social upheaval Adigun (1978) Furthermore, where the occupancy right of any land on which a residential building is erected is revoked the government (local or governor) may instead of compensation resettle the holder on any other land as alternative accommodation (section 33 LUA). While it is agreed that alternative accommodation may prevent homelessness, this is not adequate because where the price of the land stipulated for resettlement is less than the acquired land, no reimbursement to the displaced person, i.e., the LUA is silent on cases when value of the land for resettlement is less than the acquired land. In other words, where the land for resettlement is of higher value, the displaced person is required to pay the "excess value" as a loan (section 33(2) LUA). One worrisome aspect of the LUA is the prohibition of the courts in the determination of the adequacy or otherwise of the compensation payable (section $47(2)$ 
LUA). Any dispute between the "occupier" or "holder" and the government regarding compensation payable is determined by the Allocation Committee (sections 30 and 47 LUA). Glad enough the courts have extricated itself from this provision and have consistently held that the ouster clause in section 47 of the LUA is so for as it conflicts with the constitutions void.

\section{Conclusion}

This Paper examined the extent of government's compliance to procedure for the acquisition of private property. Government has the constitutional right to acquire property for public purpose. At the same time, there are laid down procedure for acquiring property. Sometimes government does not comply with procedure. The practice of acquiring "juicy” land for private economic interest by most governors run contrary to the spirit and intendment of the LUA Amokaye (2003) This practice has been judicially deprecated by the courts. As stated by Nnaemeka-Agu J. S. C. “our law reports are replete with cases in which some of such compulsory acquisitions for public purposes" turned out to be mere bogus smokescreens for malefaction Attorney General of Bendel State v Aideyan [1989]. Where there is non-compliance with procedure, Tobi J. S. C. in Provost, Lagos State College of Education \& Ors v Edun [2004], was of the view that the courts should intervene against the government and favour of the private citizen. A more difficult problem here is: what happens where government "tramples upon" and disobeys court orders? While the writer is encouraged by the judicial activism observed, more of it is recommended. Government is obliged not only to follow laid down procedure but also to obey court orders.

\section{Conflicts of Interest}

The author declares no conflicts of interest regarding the publication of this paper.

\section{References}

Adeniran v Alao [1992] 2 NWLR (Pt. 223) 350.

Adigun, O. (1978). The Land Use Act and the Principles of Equity in National Workshop on the Land Use Act. Akoka: Lagos University Press.

Ajibulu v Lawson \& Ors. [1991] 6 N.W.LR. (Pt 195) 44.

Amokaye, O. G. (2003). The Land Use Act and Governor's Power to Revoke in Land: A Critique in the Land Use Act-Twenty-Five Years after (pp. 261-262). Yaba: Lagos, Department of Private and Property Law, Faculty of Law, University of Lagos.

Arotas Grants Act (1958). Laws of the Federation of Nigeria and Lagos.

Attorney General of Bendel State v Aideyan [1989] All N.LR. 663.

Attorney General Lagos State v Sowande (1992). 8 NWLR (Pt 261) 589 at 601-602.

Awaogbo v Eze [1995] 1 NWLR (Pt 372) 393.

Crown Land Proclamation [1906] No. 13.

Dielu v Iwuno [1996] 4 NWLR (Pt 445) 622. 
Epetedo Grant Acts (1958). Laws of the Federation of Nigeria and Lagos.

Ereku v Military Governor of Mid-Western State [1974] 10 S.C. 59.

Essien, E. (2003). Land Use Act and Security in Real Estate in Nigeria. In The Land Use Act-Twenty-Five Years after (pp. 279-300). Yaba: Lagos, Department of Private and Property Law; Faculty of Law, University of Lagos.

Foreign Finance Corporation v Lagos State Development Property Corporation [1991] $3 L R C N 894$.

Glover Settlement Act (1958). Laws of the Federation of Nigeria and Lagos.

Gwar v Adole [2003] 3 NWLR 516.

Ibrahim v Mohammed [2003] 6 N.W.L.R (Pt 817), 615 at 663.

Ikpe, F. (1978). Discussions: Land Value and the Question of Compensation in National Workshop on the Land Use Act. Akoka: Lagos University Press.

Ilona v Idakwo [2003] 11 N.W.LR (Pt 830), 53 at 83-84.

In Akinde \& ors v Government of Nigeria \& Ors. (2007). Unreported, Suit No. FHC/L/ CS/629, 198 delivered on 4/7/2007 by Justice Oyindamola Olomojobi.

Interpretation Act (1958). Laws of the Federation of Nigeria and Lagos.

James, R. W. (1987). Nigerian Land Use Act: Policy and Principles (pp. 177-179). University of Ife Press Ltd.

Kratovil, R., \& Harrison, F. J. (1954). Eminent Domain-Policy and Concept. California Law Review, 42, 596. https://doi.org/10.2307/3478255

Land Ordinance (1923). Cap 133 of Tanzania.

Land Proclamation [1902] No. 13.

Land Use Act (LUA) (1978). Chapter L5 Laws of the Federation of Nigeria 2004.

Manyara Estates Ltd. \& Ors v. National Development Credit Agency [1970] E.A. 177.

Michelman, F. (1967). Property, Utility, and Fairness: Comments on the Ethical Foundations of Just Compensation Law. Harvard Law Review, 80, 1165.

https://doi.org/10.2307/1339276

Nitel v Ogunbiyi [1992] 7 NWLR 543.

Obikoya \& Sons Ltd. v Governor of Lagos State [1997] 1 NWLR (Pt 50) 385.

Ogunbanlbi v Abowaba [1951] 13 WACA 222.

Ojo, O. (2003). Effect of Land Use Act on the Institution of Customary Tenancy in the Land Use Act-Twenty-Five Years after (p. 330). Yaba: Department of Private and Property Law Faculty of Law, University of Lagos.

Oluyemi, A. F. (2005). Revocation of Rights of Occupancy: Legal Framework in Nigeria. Alausa: Lagos State Ministry of Justice.

Osho v Foreign Finance \& Anor [1991] 4 NWLR (Pt.184) 157.

Osho v Foreign Finance [1991] 4 NWLR (Pt.184) 157.

Otubu, A. (2012). Private Property Rights and Compulsory Acquisition Process in Nigeria: The Past, Present and Future. Acta Universitias Danubias Juridica, 8, 25-42.

Otubu, A. K. (2013). Compulsory Acquisition without Compensation and the Land Use Act. SSRN Electronic Journal, 3, 161. https://doi.org/10.2139/ssrn.2420039

Provost, Lagos State College of Education \& Ors v Edun [2004] 6 NWLR (Pt. 870).

Salami v Oke [1987] 9-11 SC 43.

Savannah Bank (Nig) Ltd. v Ajilo [1989] N.W.LR (Pt 97) 305. 
Teniola v Olohunkin [1999] 5 NWLR (Pt 602) 280.

The Native Lands Acquisition Ordinance [1908] No. 16.

Umeh, J. A. (1973). Compulsory Acquisition of Land and Compensation in Nigeria. London: Sweet \& Maxwell.

Yakubu, M. G. (1989). Fundamentals of Nigerian Law in Nigerian Institute of Advanced Legal, Studies (Law Series No. 2, p. 163).

Zhang, X., \& Lu, H. (2011). Compensation for Compulsory Land Acquisition in China: To Rebuild Expropriated Farmer's Long-Term Livelihood. https://escholarship.org 